\title{
CORRELATION ANALYSIS BETWEEN SEAWATER INTRUSION AND MANGROVE GREENBELT
}

\author{
Endang Hilmi ${ }^{*}$, Cecep Kusmana ${ }^{2}$, Endang Suhendang ${ }^{2}$ and Iskandar ${ }^{3}$ \\ ${ }^{1}$ Fisheries and Marine Science Faculty, Jenderal Soedirman University, \\ Jl. Dr. Soeparno, Komplek GOR Soesilo Soedarman Purwokerto, Indonesia \\ ${ }^{2}$ Forestry Faculty, Bogor Agricultural University, \\ Jl. Lingkar Akademik Kampus IPB Dramaga Bogor, Indonesia \\ ${ }^{3}$ Fisheries and Marine Science Faculty, Padjadjaran University, \\ Jl. Raya Bandung Sumedang, Hegarmanah, Jatinangor, , Indonesia
}

Received: 1 August 2016, Revised: 13 August 2017, Accepted: 17 October 2017

\begin{abstract}
CORRELATION ANALYSIS BETWEEN SEAWATER INTRUSION AND MANGROVE GREENBELT. Seawater intrusion is an entry process of seawater to land. Many factors have caused seawater intrusion from freshwater exploitation until mangrove degradation. Mangrove ecosystem is a type of forest ecosystem which has an ability to reduce seawater intrusion. This paper analyzes the estimation and prediction of seawater intrusion and correlation between widths of mangrove with seawater intrusion. The relation analysis between the width of mangrove greenbelt with seawater intrusion used an equation model to predict seawater intrusion. The research method used sampling technique, system analysis with powersim software, correlation analysis and mathematical method with trend line analysis. Results show that (1) the mangrove density in the coastal area is approximately 50-109 trees/ha. (2) Simulation results showed seawater intrusion rate was about $0.20 \mathrm{~km}_{\text {year }}{ }^{-1}$ (with mangrove as a component system), but reached 0.3 - $0.4 \mathrm{~km} /$ year (without mangrove as a component system). (3) The simulation result also showed that freshwater salinity was estimated to increase from $1.92 \mathrm{ppt}$ to $4.86 \mathrm{ppt}$. (4) The relation model between seawater intrusion and mangrove greenbelt showed that correlation coefficient was 0.97 with the equation seawater intrusion $(\mathrm{m})=2264.9 * \exp (-0.009 *$ the width of mangrove greenbelt $(\mathrm{m}))$, the correlation of mangrove width with seawater intrusion was 0.97. (5) Avicennia marina, Avicennia alba, Rhizophora styllosa, Sonneratia alba and Sonneratia caseolaris were the mangrove species that had the best ability to reduce seawater intrusion.
\end{abstract}

Keywords: Seawater intrusion, mangrove, water salinity, system analysis

ANALISIS KORELASI ANTARA INTRUSI AIR LAUT DENGAN JALUR HIJAU MANGROVE. Intrusi air laut merupakan proses masuknya air laut ke daratan. Faktor-faktor yang menyebabkan terjadinya intrusi air laut diantaranya adalah pemompaan air tawar hingga kerusakan ekosistem mangrove. Ekosistem mangrove adalah suatu ekosistem yang memiliki kemampuan untuk. mengurangi proses intrusi air laut. Penelitian ini menganalisis pendugaan dan prediksi intrusi air laut, bubungan antara lebar jalur hijau mangrove dengan intrusi air laut. Analisis hubungan antara lebar jalur hijau dan intrusi air laut menggunakan suatu model persamaan. Penelitian ini dibangun dengan menggunakan pendekatan teknik sampling, analisis sistem dengan powersim, analisis korelasi, analisis matematika dengan menggunakan "trendline". Hasil dari penelitian ini adalah (1) potensi kerapatan mangrove adalah sekitar 50 - 109 pohon/ hektar. (2) hasil simulasi menunjukan laju intrusi air laut jika ada mangrove mencapai $0,20 \mathrm{~km} /$ tahun, tapi jika tidak ada mangrove mencapai 0,3-0,4 km/tabun. (3) hasil simulasi menunjukan bahwasalinitas air tawar diduga meningkat dari 1,92 ppt bingga 4,86 ppt. (4) dari model bubungan antara intrusi air laut dan lebar jalur bijau menunjukan koefisien korelasi sekitar 0,97 dengan persamaan pendugaan intrusi air laut adalab 2264,9* exp $(-0,009 *$ lebar jalur hijau mangrove (m)), (5) jenis-jenis Avicennia marina, Avicennia alba, Rhizophora styllosa, Sonneratia alba dan Sonneratia caseolaris merupakan jenis mangrove yang memiliki kemampuan terbaik. untuk. mengurangi intrusi air laut.

Kata kunci: Intrusi air laut, mangrove, salinitas air, analisis sistem

*Corresponding author: dr.endanghilmi@gmail.com 


\section{INTRODUCTION}

Seawater intrusion occurs as an impact of mangrove degradation, seawater expansion and freshwater exploitation toward unbalanced potential of freshwater in the coastal ecosystem (Andrari, Nandang, Masmui \& Priyono, 1996). The high exploitation of freshwater, as a desirable source of water, to support different domestic activity (Hussain, Javadi, \& Sherif, 2015), industrial and agricultural sectors and pumping of groundwater (Hussain et al., 2015) are critical factors of seawater intrusion in Jakarta. The other factors are population growth, land use changes and urbanization that have also increased the pressure on the source of freshwater to the extent leading to the extraction of groundwater as the alternative to surface water to cope with the scarcity of freshwater resources (Narayan, Schleeberger \& Bristow, 2007). Seawater intrusion usually occurs due to rapid disturbances which give negative impact for coastal sustainability as a risk to coastal aquifers in the coastal area (Morgan \& Wernera, 2015). Seawater extent represents the condition of the respective aquifers under stress (Morgan \& Wernera, 2015).

The worst effects of seawater intrusion for environment are reduction of freshwater, agriculture degradation, increasing water salinity, soil degradation (Badarudeen, Damodaran, Sajan \& Padmala, 1996), destruction of water gradient, and unbalance in freshwater potential (Todd 1980). The seawater intrusion in Jakarta is a specific case of seawater intrusion in Indonesia. The high degradation and deforestation of mangrove ecosystem causes increased freshwater degradation and also the degradation of soil physic is another causing factor of seawater intrusion. This condition shows that mangrove vegetation has the function of retaining and reducing the potential and effect of seawater intrusion (Ellison \& Farmsworth, 1997; Kairo, Dahdouh-Guebas, Bosire \& Koedam, 2001).

Mangrove in Jakarta has many functions, for example, buffering of coastal area, habitat of flora and fauna and reduction of seawater intrusion. However, the important functions of mangrove ecosystem are the preservation of habitat for spawning, representing nursery and feeding grounds for several aquatic organisms (Nagelkerken et al., 2008; Kusmana, 2005; Hutchings \& Saenger, 1987; Snedaker \& Snedaker, 1984), reducing and retaining heavy metal pollution (Machado, Moscatelli \& Rezende, 2002; Hilmi et al., 2014), reducing abrasion (Cai, Su, Liu, Li, \& Lei, 2009; Hilmi 2014), reducing of tidal wave effect (Mazda, Kanazawa \& Wolanski, 1995; Massel, Furukawa \& Brinkman, 1999), and buffering of coastal stabilities (Mazda et al., 1995). To support this function, the mangrove ecosystem has the specific vegetations that are growing to interface between terrestrial and ocean ecosystem (Kusmana, 2005; Kathiresan \& Bingham, 2001; Parvaresh et al., 2011; Hilmi, Syakti \& Siregar, 2014). But, an important function of the mangrove in Jakarta is the function to reduce seawater intrusion.

The mangrove ecosystem has ability to reduce seawater intrusion because mangrove can eliminate the effect of salinity, $\mathrm{pH}$, pyrites and anaerobe conditions. The mangrove ecosystem also has salt-excreting gland, saltaccumulating gland and salt-excluder gland (Bengen \& Dutton, 2004), specific root (Alongi, Wattayakorn, \& Boyle, 2004), root activity, salinity absorption, salinity accumulation, specific growth (Lunstrum \& Chen, 2014) and another metabolism to reduce impact of seawater in mangrove metabolism. Therefore, the degradation and deforestation of mangrove ecosystem causing reduction of the mangrove function to reduce seawater intrusion. The objective of this research is to simulate correlation between seawater intrusion with the width of mangrove ecosystem. The research used Stella software, trend line analysis and datafit analysis. 

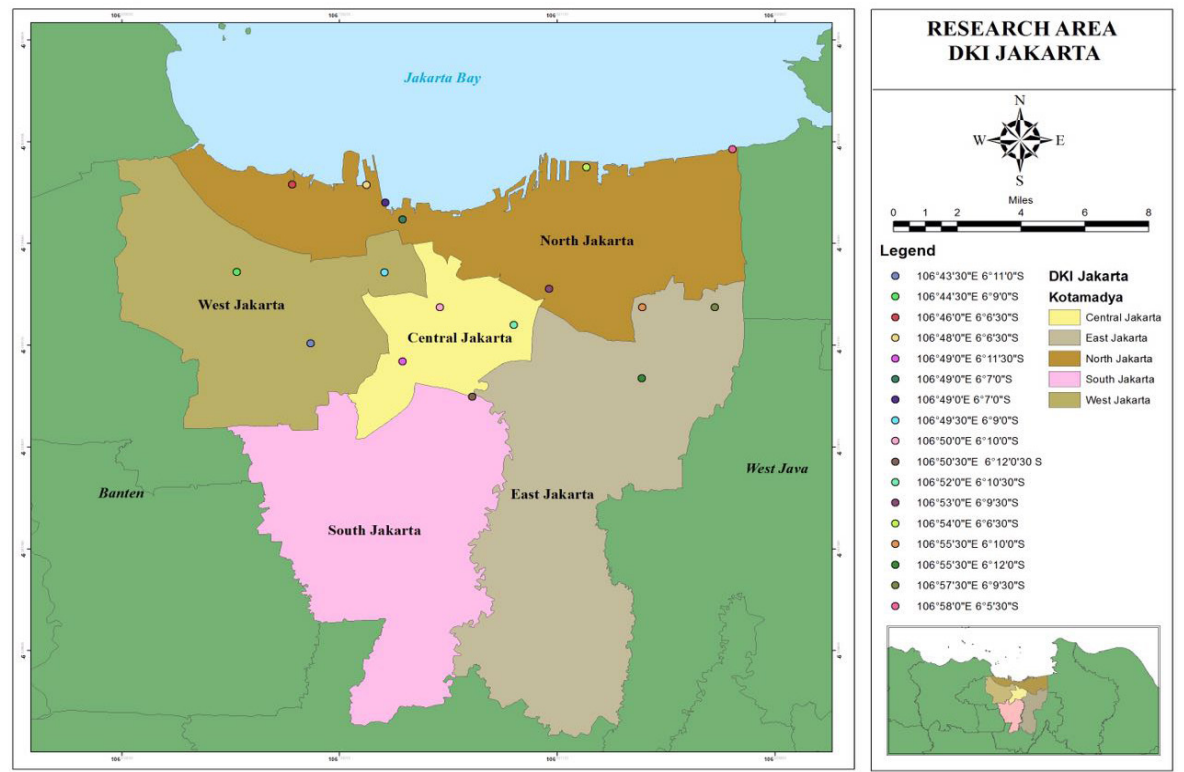

Remarks: $\mathrm{O}=$ sampling plots

Figure 1. Research sites

\section{MATERIAL AND METHOD}

\section{A. Study Site}

This research was conducted in North Jakarta (Figure 1). The research area is part of the coastal ecosystem (5 $19^{\circ} 12^{\prime \prime}$ South Latitude (N) - 623'54" South Latitude (S) and $106^{\circ} 22^{\prime} 42^{\prime}$ East Longitude (W) - 106 '58'18” East Longitude (E)) as the estuarine ecosystem to support water distribution from Angke, Ciliwnng, and Cisadane rivers, as well as the North Java Ocean. Seawater intrusion is a big problem in North Jakarta. The high exploitation of freshwater with pumps and mangrove degradation (Hilmi, 1998) were the triggering factors of seawater intrusion. The locations of research for analysis of mangrove domination were Greenbelt North Jakarta, Suaka Margasatwa Muara Angke, and Ecotourism in North Jakarta and Silvofishery Area in North Jakarta. The sampling plots were U1 (106 $\left.43^{\prime} 30^{\prime \prime} \mathrm{E}-06^{\circ} 11^{\prime} 00^{\prime \prime} \mathrm{S}\right)$, U2 (106 44'30"E - 06 09'00"S), U3 (106 46'00'"E

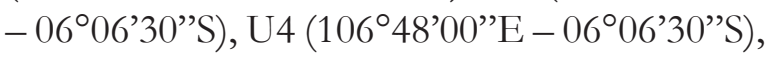
U5 (106 49'00"'E - 06 $\left.16^{\circ} 30^{\prime} " \mathrm{~S}\right)$, U6 (106 49'00”E - 0607’00”S), U8 (10649’10”E
- 0607'00”S), U9 (106 49'30"E - 06 09'00"S), U10 (106 $50^{\circ} 00^{\prime \prime} \mathrm{E}-$ 060'00"S), U11 (106 50’30”E - 06²'30”S),U12 (10652’00”'E -06¹0’30”S), U12 (106 53’00”'E-0609'30”S), U13 (106 $\left.54^{\circ} 00^{\prime \prime} \mathrm{E}-0^{\circ} 06^{\prime} 30^{\prime \prime} \mathrm{S}\right), \quad \mathrm{U} 14$ (106 55'30”'E-06 $10^{\circ}$ '00”'S), U15 (106 55'30”'E

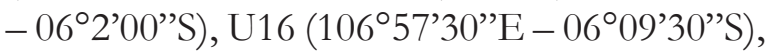
U17 (10658'00”'E-0605’30”S).

\section{B. Research Procedures}

\section{Research Variables}

The variables of seawater intrusion were the distance of seawater intrusion, water quality, water salinity, soil porosity, the density of mangrove ecosystem, and the width of mangrove greenbelt.

\section{Sampling Technique}

The collection of research data used clusters with stratified sampling (Cochran, 1997) following the density of mangrove. The sampling design to observe the density of mangrove, the area of mangrove ecosystem, water salinity, distance of seawater, soil properties and the width of mangrove greenbelt used 17 sampling stations with three 
Table 1. Standard criteria of mangrove degradation (Ministry of Environment Decree No 2004)

\begin{tabular}{lccc}
\hline \multirow{2}{*}{ Degradation class } & Density criteria & $\begin{array}{c}\text { Mangrove } \\
\text { coverage }\end{array}$ & Mangrove density level (trees $/$ ha) \\
\hline No degradation & Dense & $\geq 75$ & $\geq 1500$ \\
\cline { 2 - 4 } & moderate & $\geq 50-\geq 75$ & $\geq 1000-<1500$ \\
\hline Degradation & rare & $<50$ & $<1000$ \\
\hline
\end{tabular}

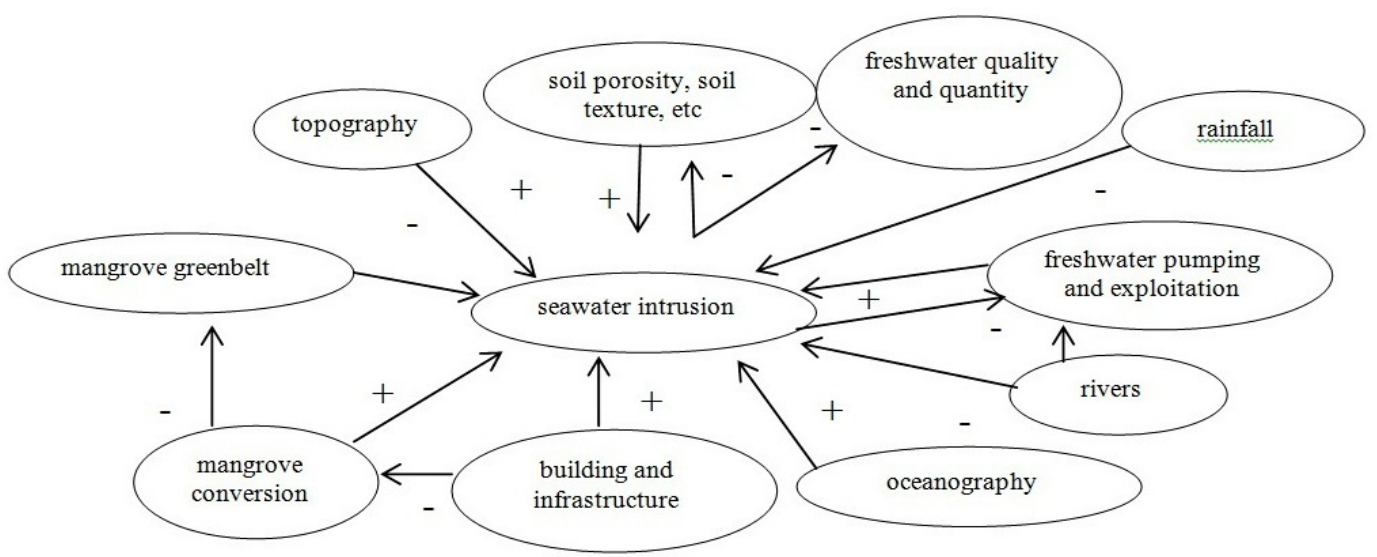

Figure 2. Causal loop modeling of seawater intrusion

replications. The number of sampling plots were (1) North Jakarta (7 stations), (2) West Jakarta (3 stations), (3) Central Jakarta (3 stations) (4) East Jakarta (3 stations) and (5) South Jakarta (only one station).

\section{Width and Area of Mangrove Greenbelt}

The research procedure to analyze the width and the potential area of mangrove greenbelt used geographical information system (Prahasta, 2008; Purwadhi 2001) to overlay satellite imageries for 1980, 2000, 2010, and 2016. The satellite imagery interpretation used ERR mapper software. After interpreting with ERR mapper, the width and mangrove area was analyzed by Arc GIS 9.1.

\section{Mangrove Density}

The density of mangrove ecosystem (collection of all species) used the modification of quadrant transect method (Kusmana, 1997). The collection of data used plot sizes of 10 $\mathrm{m} \times 10 \mathrm{~m}$ for mangrove trees, $5 \mathrm{~m} \times 5 \mathrm{~m}$ for mangrove saplings and $2 \mathrm{~m} \times 2 \mathrm{~m}$ for mangrove seedlings. These activities were carried out in Greenbelt North Jakarta, Suaka Margasatwa Muara Angke, Ecotourism in North Jakarta, Silvofishery Area in North Jakarta and other areas as research stations. To calculate the density of mangrove the equation below was used (Kusmana, 1997; Bengen, 2002).

$\mathrm{Di}=\frac{n i}{A}$

Where:

Di $=$ density, $n i=$ number of individuals (seedlings, saplings and trees) and $A=$ mangrove area (ha)

For degradation of mangrove ecosystem the mangrove degradation criteria was used from Menteri Lingkungan Hidup No. 201 in 2004 (Table 1) which was divided into degraded and not degraded. 


\section{Water Salinity, Soil Salinity and Soil Porosity}

The measurement of water salinity used APHA (2005) method with hand refractometer. The measurement of soil texture used gravimetric method. The soil analysis was done at the Soil Laboratory of Land Resources and Soil Departement, Bogor Agricultural University (Soil Research Department, 2005).

\section{Potential of Seawater Intrusion}

The measurement of seawater intrusion distances used water salinity method in the water pump with hand refractometer. The sampling points of water salinity were marked by global positioning system to measure the distance of seawater intrusion $(\mathrm{km})$.

\section{Data Analysis}

1. Mapping of Mangrove Greenbelt

The mapping of mangrove greenbelt used Arc GIS 9.1 to overlay mangrove area from 1980, 2000, 2010 and 2016. These data were used to calculate mangrove area in Jakarta.

\section{Modeling of Seawater Intrusion.}

The seawater intrusion model used casual loop system among variables to develop the seawater intrusion model. The variables of causal loop system in this model were freshwater demand, oceanography effect, mangrove potency, river debits, runoff, rainfall, topography, and freshwater resource (Figure 2).

\section{Modeling of Water Salinity}

The modeling of water salinity used casual loop system among soil and water salinity. The variables of this model were $\mathrm{Ca}, \mathrm{Mg}, \mathrm{Na}, \mathrm{K}$, water salinity and $\mathrm{pH}$ in mangrove and other areas.

\section{Relation between Mangrove Greenbelt and Seawater Intrusion}

The relation between seawater intrusion and mangrove greenbelt used the trend line analysis 1 with the equation below (Steel \& Torrie, 1980; Hilmi et al, 2014; Hilmi, 1998; Muhidin et al., 2011).
Yij $=f(X i)$

Where:

Yij $=$ distance of seawater intrusion $(\mathrm{Km})$

$\mathrm{Xi}=$ width of mangrove $(\mathrm{m})$

$\mathrm{f}=$ mathematic function (exponential, linier, etc.)

The trendline equation was a statistic method to construct and select the best equation of seawater intrusion. This equation interpreted the estimation and relation between the width of mangrove greenbelt and the distance of seawater intrusion.

\section{III.RESULT AND DISCUSSION}

\section{A. Density of Mangrove Ecosystem}

The garbage, domestic waste, agriculture waste, pollution of oils and heavy metals, deforestation and conversion of mangrove ecosystem were the triggering factors of the mangrove density (Hilmi, 1998) The mangrove density in Table 2 show the classification of mangrove density in Jakarta. Mangrove must have tolerance toward extensive erosion, abrasion (Paris et al., 2009), heavy metal pollution (Wang et al., 2012), soil sedimentation (Ferreira, Vidal-Torrado, Otero \& Macias, 2010), seawater inundation, sea tide, garbage, pollution (Krauss et al., 2008), oceanography, freshwater supply (Finkl, 2004) and climate change (Robins et al., 2016) to live and grow in the coastal area of Jakarta. Mangrove has good grows when water salinity is between $10-30$ ppt and $\mathrm{pH}$ is about 6-9 (Hutchings \& Saenger, 1987; Snedaker \& Snedaker, 1984) with soil textures which are sandy clay, clayey sand, silty sand, sandy silt, clayey silt, silty clay, clay, sand and silt (Pirzan, Gunarto, Daud \& Burhanuddin, 2004).

Table 2 shows that the mangrove area in the greenbelt, ecotourism, and preservation areas of Muara Angke and Silvofishery had differences in density and species domination of the mangrove vegetation. Table 2 also shows that Rhizophora apiculata, Rhizophora mucronata, Avicennia alba and Sonneratia alba were the mangrove species dominating in North Jakarta, 
Table 2. Mangrove density in Jakarta.

\begin{tabular}{|c|c|c|c|c|c|}
\hline \multirow[b]{2}{*}{ Mangrove Area } & \multirow{2}{*}{ Species } & \multicolumn{3}{|c|}{ Mangrove density $\left(\right.$ trees ha ${ }^{-1}$ ) } & \multirow{2}{*}{$\begin{array}{c}\text { Class of forest } \\
\text { degradation (Kusmana, } \\
\text { 2005; Hilmi et al, 2011, } \\
\text { KemenLH 201, 2004) }\end{array}$} \\
\hline & & Seedlings & Saplings & Trees & \\
\hline \multirow{2}{*}{$\begin{array}{c}\text { Greenbelt North } \\
\text { Jakarta }\end{array}$} & Avicennia alba & 30000 & 2691 & 92 & \multirow{2}{*}{ rare } \\
\hline & Rhizophora mucronata & 40000 & 883 & 17 & \\
\hline \multirow{2}{*}{$\begin{array}{c}\text { Suaka } \\
\text { Margasatwa } \\
\text { Muara Angke }\end{array}$} & Rhizophora apiculata & 2500 & 1000 & 0 & \multirow{2}{*}{ rare } \\
\hline & Sonneratia alba & 2000 & 1183 & 50 & \\
\hline \multirow{3}{*}{$\begin{array}{l}\text { Ecotourism in } \\
\text { North Jakarta }\end{array}$} & Avicennia alba & 30000 & 2773 & 127 & \multirow{3}{*}{ rare - moderate } \\
\hline & Rhizophora apiculata & 0 & 483 & 17 & \\
\hline & Rhizophora mucronata & 13333 & 1350 & 50 & \\
\hline \multirow{3}{*}{$\begin{array}{l}\text { Silvofishery Area } \\
\text { in North Jakarta }\end{array}$} & Avicennia alba & 0 & 360 & 40 & \multirow{3}{*}{ rare } \\
\hline & Rhizophora apiculata & 0 & 252 & 15 & \\
\hline & Rhizophora mucronata & 0 & 218 & 15 & \\
\hline
\end{tabular}

because these species have the highest tolerance for garbage, domestic waste, oil, heavy metal and sea inundation. The mangrove density in Jakarta showed that (1) mangrove density in the greenbelt area was 1650 trees ha $^{-1}$ (diameter $>4 \mathrm{~cm}$ ) and 109 tree ha-1 (diameter $>10 \mathrm{~cm}$ ) (rare), (2) Suaka Margasatwa Muara Angke had density about 433 trees ha-1 (diameter $>4 \mathrm{~cm}$ ) and 50 trees $\mathrm{ha}^{-1}$ (diameter $>10 \mathrm{~cm}$ ) (rare), (3) ecotourism area had density about 2800 trees $\mathrm{ha}^{-1}$ (diameter $>4 \mathrm{~cm}$ ) and 194 trees $\mathrm{ha}^{-1}$ (diameter $>10 \mathrm{~cm})$ (rare - moderate) and (4) silvofishery area had density of 900 trees ha ${ }^{-1}$ (diameter $>4 \mathrm{~cm}$ ) and 70 trees ha ${ }^{-1}$ (diameter $>10 \mathrm{~cm}$ ) (rare).

The low density of mangrove trees (Macintosh, Ashton, \& Havanon, 2002) showed the degradation of mangrove ecosystem in Jakarta and had been categorized as rare moderate density (Kusmana, 2005, Hilmi et al., 2011 and KLHK, 2004). Macintosh et al., (2002) noted that the main reason for the loss and degradation and deforestation of mangrove were population pressure, wood exploitation, mangrove conversion, sand mining and coastal conversion. Another factors effecting the density and stabilization of mangrove ecosystem were silviculture-oriented, economic and ecological conditions (Lunstrum \& Chen, 2014).

In Jakarta, the degradation and deforestation of mangrove ecosystem were the key factors for seawater intrusion. The integration between deforestation and degradation of mangrove ecosystem with freshwater pumping, mangrove conversion, settlement, industry and hotel caused increasing seawater intrusion in Jakarta. The conversion of the mangrove ecosystem in Jakarta was a triggering factor for losing the role of the mangrove ecosystem to reduce seawater intrusion. The rate of mangrove degradation, conversion and mortality increasingly gave impact for reducing the function of mangrove as the buffer area to preserve coastal stabilization and to reduce negative impact of seawater intrusion.

Redesigning of rehabilitation and replanting activity of mangrove ecosystem aimed to reduce sea water intrusion based on the natural regeneration of mangrove species in North Jakarta. Basically, the mangrove ecosystem in Jakarta is going to do a succession process, because mangrove in Jakarta has $2000-40.000$ individual/ha (seedlings) and $400-1.663$ 
Table 3. Area of mangrove ecosystem in North Jakarta Coast

\begin{tabular}{ccc}
\hline No. & Year & Mangrove Area (ha) \\
\hline 1. & 1980 & 1165.33 \\
2. & 2000 & 168.00 \\
3. & 2010 & 171.35 \\
4. & 2016 & 165.28 \\
\hline
\end{tabular}
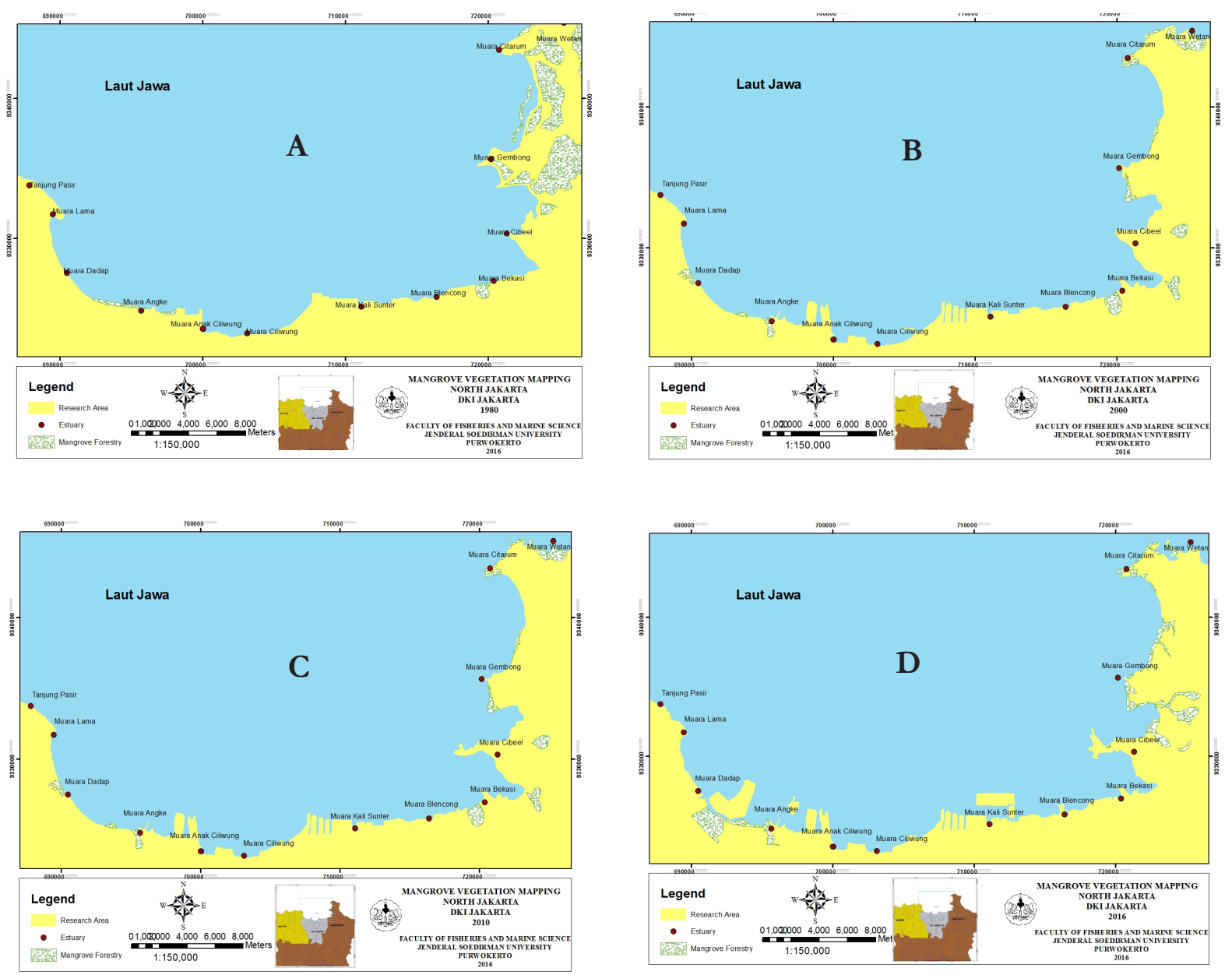

Remarks:

A: North Jakarta Coast in 1980, C: North Jakarta Coast in 2010,

B: North Jakarta Coast in 2000, D: North Jakarta Coast in 2016

Figure 3. The trend of mangrove ecosystem in Jakarta

individual/ha (saplings). The maintenance activities of seedlings and saplings will make mangrove grow well. The activity of mangrove succession is an effort to support mangrove growth in the coastal area (Chebo, 2009; Kathiresan \& Rajendran, 2005; Kusmana, 2005; Macintosh et al., 2002). The existence of seedlings and saplings of mangrove vegetation in the succession of mangrove must be conserved as the dynamic process of mangrove ecosystem to reach vegetation climax (Kusmana, 2005; Lopes et al., 2009; Macintosh et al., 2002).

The other activity to conserve mangrove 
ecosystem in Jakarta was mangrove plantation (Kusmana, 2005). The mangrove plantation must see the complex and dynamic system of mangrove environment (Lopes et al., 2009). The mangrove plantation in Jakarta must select mangrove species based on best domination in Jakarta area, because these species have the best possibility to survive and density to support the successful mangrove rehabilitation. The species to support the rehabilitation program in mangrove ecosystem were: Rhizophora apiculata, Rhizophora mucronata, Rhizophora stylossa, Avicennia alba, Sonneratia alba and Bruguiera spp.

\section{B. Dynamic Analysis of Mangrove Ecosystem}

The dynamic of mangrove ecosystem showed the rate of mangrove regeneration and conversion (Table 3 and Figure 3). Based on data from 1997, the mangrove area in Jakarta was 322.6 ha (Hilmi, 1998) of which 169.9 ha was mangrove forest area and 152.7 ha was for other usage. The degradation rate of mangrove ecosystem reached $9.3 \%$ year. The biggest factor of mangrove degradation in Jakarta was the conversion of mangrove for settlement and other activity

Jakarta was moderate-high. The mangrove areas in Jakarta were 1165.33 ha (1980), 168 ha (2000), 171.35 ha (2010) and 165.28 ha (2016). These data also showed that the area in Jakarta decreased by 1000.05 ha (over 36 years) from 1165.33 ha (1980) to 165.28 ha (2016).

Table 2 and Figure 3 show that the rate of mangrove degradation and deforestation in Jakarta had a positive correlation with mangrove density (Table 1). The high rate of mangrove conversion and mortality were the key factors for mangrove density and degradation. Basically, the mangrove ecosystem has high sensitivity toward environment change and conversion. Sedimentation, garbage, industry and domestic waste, mangrove cutting and mangrove exploitation, freshwater flood, seawater flood and long inundation were the biggest factors of mangrove degradation and deforestation (Chebo, 2009; Krauss et al.,
2008 and Xiao, Wang \& Chen, 2010). The mangrove ecosystem was also sensitive and responsive toward climate change and human activity, the eco-geo-morphological processes and pressures (Al-Nasrawi, Jones \& Hamilton, 2016). Therefore mangrove degradation and deforestation in Jakarta caused mangrove to stunt, dying, degradation of mangrove structure and mortality (Ellison \& Farmsworth, 1997; Ellison, 2002).

The high mangrove degradation and deforestation also caused mangrove recovery and regeneration to be very difficult. Mangrove vegetation needs a long time to regenerate and recover to reach tree phase. The mangrove degradation was a triggering factor for coastal disasters including seawater intrusion. According to Salampessy et al., (2015), mangrove degradation, mangrove conversion, water unbalance and destruction of water gradient increased seawater intrusion in Jakarta. The conversion of mangrove ecosystem also was due to accelerated sea-level rise, seawater intrusion and land subsidence.

\section{Prediction of Seawater Intrusion in Jakarta}

Factors to predict seawater intrusion are: freshwater demand from industrial activity, settlement and hotel, sea tide, season, oceanographic, mangrove density, rivers' debit, source of freshwater and topography. Prediction of seawater intrusion in Jakarta with or without mangrove is shown in Table 4, Figure 4 and Figure 5. They show the existence of seawater in the coastal area, degradation of fresh water gradient, freshwater aquifer damage, and overexploitation of freshwater were the important factors of seawater intrusion in the coastal area of Jakarta (Andrari et al., 1996). The environmental degradation (seawater and freshwater aquifer) caused the change in hydraulic gradient of aquifer, accelerated the progressive landward invasion of seawater toward the abstraction wells, destructive for the chemical quality, water pollution and surrounding groundwater followed by other 
Table 4. The prediction of the distance of seawater intrusion along Jakarta Coast

\begin{tabular}{ccc}
\hline \multirow{2}{*}{ Year Prediction } & \multicolumn{2}{c}{ Intrusion in Jakarta $(\mathrm{km})$} \\
\cline { 2 - 3 } & With mangrove & Without mangrove \\
\hline 1 & 1.85 & 8.90 \\
2 & 2.05 & 9.25 \\
3 & 2.24 & 9.59 \\
4 & 2.44 & 9.94 \\
5 & 2.64 & 10.29 \\
6 & 2.84 & 10.64 \\
7 & 3.03 & 10.98 \\
8 & 3.23 & 11.33 \\
9 & 3.43 & 11.68 \\
10 & 3.63 & 12.03 \\
\hline
\end{tabular}

problems such as decrease of freshwater availability, human health and ecosystem damage (Hussain et al., 2015; Howard, 1987; Patel \& Shah, 2008).

Basically, the coastal aquifers are very vulnerable toward seawater intrusion because of the overexploitation of the coastal aquifers. Seawater intrusion models are more efficient tools for coastal aquifer management and protection. The disperse interface approach explicitly represents a transition zone or a mixing zone of the freshwater and saltwater within an aquifer due to the effects of hydrodynamic dispersion (Pramada \& Mohan, 2015; Park, Kim, Yum, \& Yeh, 2012). The instability of freshwater and seawater system in coastal aquifers due to overexploitation produces the landward movement of the seawater wedge. The hydraulic barriers method has the function to reduce seawater invasion with the injection of freshwater and raising aquifer's hydraulic head. The sensitivity of the rate and location to inject water used two laboratory-scale sandboxes under hydraulic confinement to measure the wedge length reduction. The coastal aquifers are principal sources of freshwater in various parts of the world due to their groundwater quantity and quality, suitable to cover water needs of cities, rural villages and agricultural and industrial activities (Acosta \& Donado, 2015; Carruthers et al., 2013)
The seawater intrusion prediction with or without mangrove vegetation showed that mangrove ecosystem has an important role in reduction of seawater intrusion in Jakarta. The simulation model also explained the role and function of mangrove to prevent, release and reduce seawater intrusion (Soerianegara, 1987; Hilmi, 1998). The simulation of seawater intrusion model with or without mangrove vegetation used freshwater demand for industry, settlement, community, seawater tide, seawater inundation, rivers' debit, freshwater capacity, topography, rain intensity and mangrove density as elements of this model (Figure 4).

The design of seawater intrusion model used freshwater demand for industry $1,98 \mathrm{~m}^{3} \mathrm{t}^{-1}$, domestic need $4.31 \mathrm{~m}^{3} \mathrm{t}^{-1}$, hotel and settlement $2.11 \mathrm{~m}^{3} \mathrm{t}^{-1}$, seawater tide $0.61 \mathrm{~m}$, seawater level approximately $0.47 \mathrm{~m}$, and domestic freshwater demand in Jakarta approximately $11.3 \mathrm{~m}^{3} \mathrm{t}^{-1}$, topography between $-7 \mathrm{~m}$ to 10 meter, rain intensity $1750 \mathrm{~mm}_{\text {year }}{ }^{-1}$, river debit $13.23 \mathrm{~m}^{3} \mathrm{dt}^{-1}$ , and mangrove density and mangrove area in seawater Based on seawater mapping it showed that (1) if the width of mangrove greenbelt was $75 \mathrm{~m}$, the distance of seawater intrusion reached $1 \mathrm{~km}$, (2) if the width of mangrove greenbelt was $90 \mathrm{~m}$, the distance of seawater intrusion was approximately $950 \mathrm{~m}$, (3) if the width of mangrove greenbelt $115 \mathrm{~m}$, the distance of seawater intrusion reached $800 \mathrm{~m}$, 


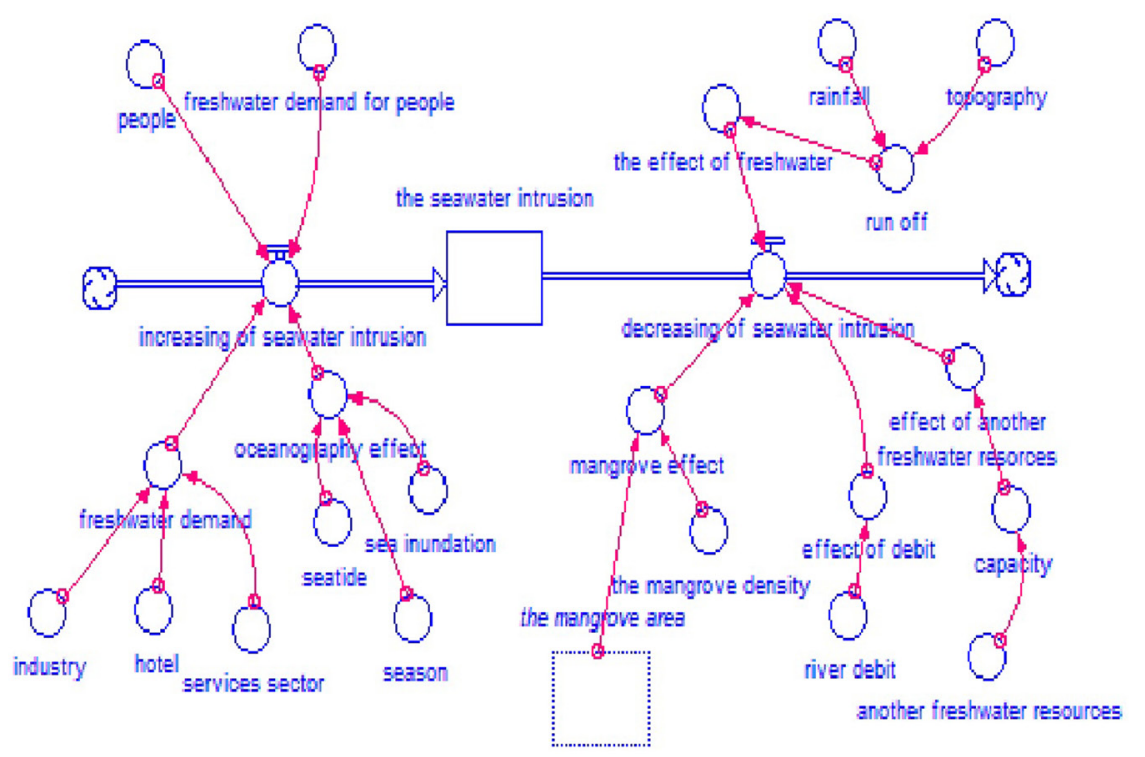

Figure 4. Diagram of modeling seawater intrusion

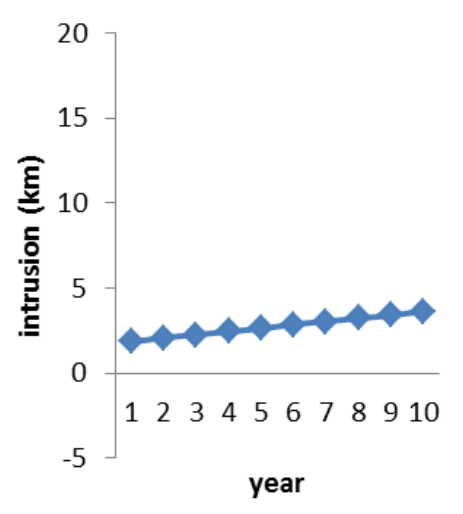

a

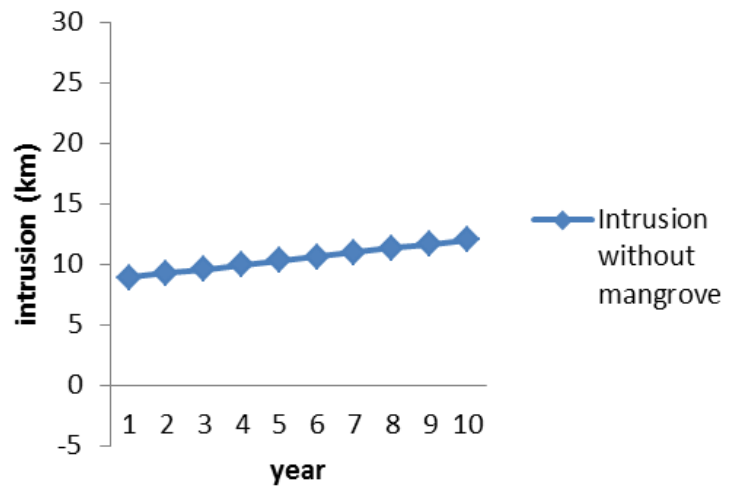

b

Remarks :

a. The trend in distance of seawater intrusion with mangrove

b. The trend in distance of seawater intrusion without mangrove

Figure 5. The trend of seawater intrusion prediction

(4) if the width of mangrove was more than 115 meter, the distance of seawater intrusion was $500 \mathrm{~m}-600 \mathrm{~m}$, and (5) if the width of mangrove $<85$ meters, the distance of seawater intrusion reached until 1650 meters.

The simulation model of seawater intrusion shows the combination between freshwater consumption, soil texture, soil pore, soil porosity, topography, (Hilmi, 2003), organic matter (Kairo et al., 2008), density and mangrove zonation (Kairo et al., 2008; Bosire et al., 2005). The simulation model showed that the rate of seawater intrusion is about $0.20 \mathrm{~km}$ (with mangrove as a system component), and is about $0.30-0.40 \mathrm{~km}$ (without mangrove as a system component). The trend of seawater 
intrusion in Jakarta is not different from seawater intrusion in Semarang which has increased by $0.575 \mathrm{~km}^{2}$ years ${ }^{-1}$ (Suhartono, Purwanto \& Suripin, 2015).

Table 3 also shows that mangrove has an important role to play to reduce the rate of intrusion in Jakarta. Mangrove has ability to reduce seawater intrusion because (1) mangrove vegetations have salt excreation gland, salt accumulation gland, and salt excluder gland (Hamilton \& Snedaker, 1984; Hilmi, 2014; Kusmana, 2005; Snedaker \& Snedaker, 1984), (2) the decomposition of mangrove litter as the organic matter resource impacts the reduction of the salinity of freshwater. (Bosire et al., 2005), (3) root of mangrove vegetation has ability to prevent seawater penetration to land, (4) the root activity is a mangrove metabolism to recover soil characteristic and dilute salinity of soil water, (5) the extract matter metabolism is mangrove ability to decrease salinity of water (Sigalingging, 1985) and (6) the spesific architecture of mangrove root systems has function to release the negative impact of seawater intrusion (Purnobasuki \& Suzuki, 2004).

In Jakarta, the existence of mangrove is a fragile ecosystem because conversion, illegal logging, waste, oil pollution, pesticide pollution, domestic waste, industry waste, etc occures in the mangrove ecosystem. But, mangrove is a resilient ecosystem to live in a wide range of environmental variables (Petrakis et al., 2016), including in freshwater. However, these factors still contribute to have a big impact on the sustainability of mangrove ecosystem in Jakarta. The degradation and mortality of mangrove ecosystem are critical factors (Xiao et al., 2009) that will increase seawater intrusion in Jakarta.

Basically, the ability of mangrove ecosystem to reduce seawater intrusion (Hilmi, 1998; Hilmi et al., 2014) is an important role to keep the sustainability of the ecological function and life supporting system to reduce and prevent seawater entry to land (Hilmi, 1998; Soerianegara, 1987). Seawater intrusion also has correlation with mangrove density which influences the litter degradation process, nutrient demineralization and efficiency of the ecological processes (Bosire et al., 2005). Mangrove also has ability to breakdown organic material in the mangrove ecosystem thus rapidly supporting the recycling of organic matter (Marchand, Allenbach \& Lallier-Vergès, 2011; Bosire et al., 2005), increase ability to adsorbent, adsorption and absorption mechanism for organic matter, salinity and other material (Oo et al., 2009), increase supporting the nitrogen process in coastal ecosystem (Kadlec, 2008), reduce water pollution (Narayana et al., 2007) and has high primary productivity. The high productivity is often attributed to high litter degradation rates and efficient recycling of nutrients (Bosire et al., 2005) and finally give effect to release seawater intrusion (Cochard et al., 2008). Based on this reason, mangrove is an important ecosystem as the buffer ecosystem to reduce seawater intrusion (Sigalingging, 1985). Therefore mangrove rehabilitation and area redesign in Jakarta aimed to increase mangrove function to reduce seawater intrusion (Macintosh et al., 2002; Huang et al., 2003) is needed.

\section{Effect of Seawater Intrusion on Freshwater Quality}

The salinity degree of freshwater was a variable to predict seawater intrusion in the coastal area, and $\mathrm{Ca}, \mathrm{Mg}, \mathrm{Na}, \mathrm{Cl}$ and $\mathrm{K}$ were used as potential variables to predict the freshwater quality in Jakarta coast. The rate of salinity degree also showed the influence of mangrove ecosystem for prediction of freshwater quality in the seawater intrusion area (Table 5, Figure 6 and 7). This simulation model used mangrove as a main factor to determine the trend of water salinity, because mangrove has secreting, filtering and accumulating processes to reduce water salinity in the coastal area (Hamilton \& Snedaker, 1984; Hilmi, 2014; Kusmana, 2005; Snedaker \& Snedaker, 1984). The result of this simulation model showed the correlation between mangrove ecosystem with salinity degree of freshwater in the coastal area. 
Table 5. Rate of water salinity in Jakarta

\begin{tabular}{cc}
\hline $\begin{array}{c}\text { Year } \\
\text { prediction }\end{array}$ & $\begin{array}{c}\text { Rate of Water Salinity } \\
(\mathrm{ppt})\end{array}$ \\
\hline 1 & 1.92 \\
2 & 2.25 \\
3 & 2.57 \\
4 & 2.90 \\
5 & 3.23 \\
6 & 3.55 \\
7 & 3.88 \\
8 & 4.20 \\
9 & 4.53 \\
10 & 4.86 \\
\hline
\end{tabular}

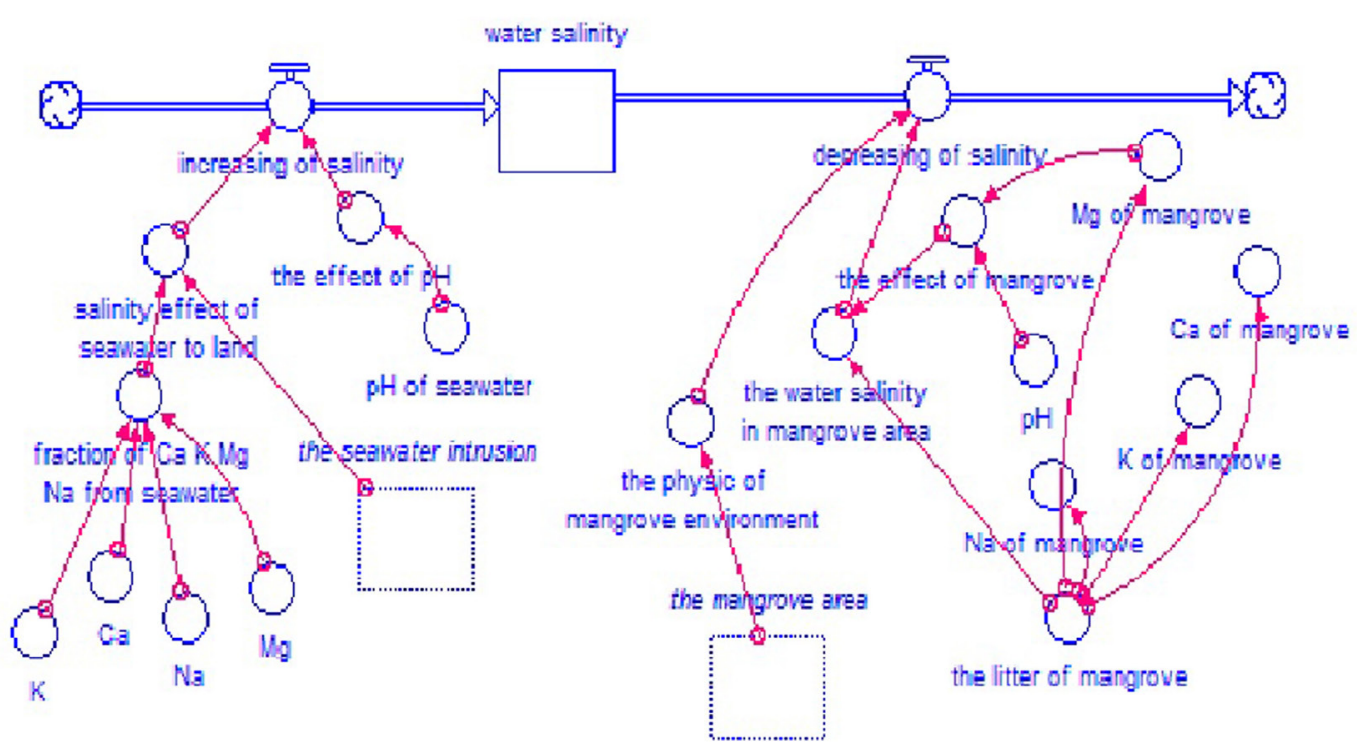

Figure 6. The modeling diagram of water salinity

The result of this simulation model in Figure 7 and Table 5 showed a raising trend of water salinity in Jakarta. The degree of water salinity in Jakarta was predicted between 1.92 ppt (the first year) to $4.86 \mathrm{ppt}$ (year ten). The degree of water salinity was an indicator to analyze sea water intrusion. Todd (1980) noted that seawater intrusion occurred because the quantity of freshwater supply was less than seawater supply causing seawater completely entering into the groundwater as the seawater process in the coastal area.

The rate of seawater intrusion showed an increasing exploitation of freshwater by domestic, hotel, and industry pump. The increasing seawater intrusion caused the high rate of existence and distribution of water salinity in the freshwater ecosystem. The progressive rate of seawater entry to land became a water pollutant for freshwater in Jakarta. The positive trend of seawater intrusion in Jakarta showed significant correlation between mangrove 


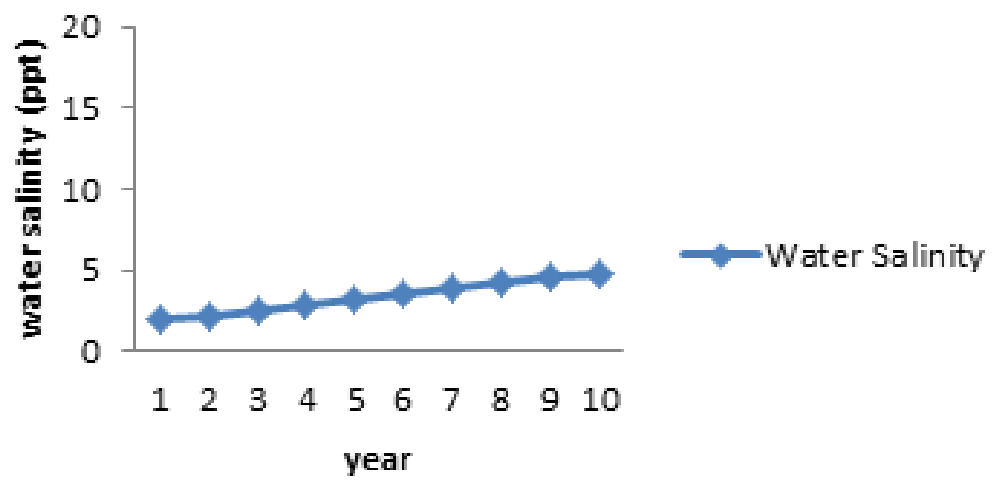

Figure 7. Trend of water salinity in Jakarta

degradation and freshwater demand with seawater intrusion as the significant effect for a destructive barrier line between freshwater and seawater. This condition was a triggering factor for the incidence of seawater intrusion.

\section{E. Equation between Seawater Intrusion and Mangrove Greenbelt}

Seawater intrusion and mangrove greenbelt were the variables in the model for estimation of seawater intrusion and the width of mangrove greenbelt. The trend line analysis was used to construct this model (Figure 8). The first equation showed that the distance of seawater intrusion $(\mathrm{m})=2264.9 * \exp (-0.009 *$ the width of mangrove greenbelt $(\mathrm{m})$ ) with determination coefficient $\left(\mathrm{R}^{2}\right)=94.65 \%$ (Figure 7 ). The second equation showed that the width of mangrove greenbelt $(\mathrm{m})=781.76 * \exp (-0.002$ * seawater intrusion $(\mathrm{m})$ ) with determination coefficient $\left(\mathrm{R}^{2}\right)=62.62 \%$.

Figure 8 shows that the correlation between seawater intrusion and mangrove width was of a negative exponential model. This model showed that mangrove greenbelt had negative correlation with seawater intrusion. Mangrove greenbelt has the role to reduce seawater intrusion (Hilmi, 2003; Ellison \& Farmsworth, 1997; Kairo, Dahdouh-Guebas, Bosire, \& Koedam, 2001). This equation also showed that mangrove greenbelt was a main indicator of seawater intrusion in the coastal area. The ability of mangrove ecosystem to reduce seawater intrusion was the linkages with salt excretion, accumulation and exclusion activity. Based on the result of this equation it shows that to release seawater intrusion (the distance $=0 \mathrm{~m})$ there is a need of a mangrove greenbelt approximately of $1.000 \mathrm{~m}$ width. and based on the optimal line, Jakarta needs to optimize a mangrove greenbelt of more than $115 \mathrm{~m}$ in width.

\section{F. Strategy to Reduce Seawater Intrusion}

This strategy aimed to reduce seawater intrusion. The design of mangrove rehabilitation used the following systems:(1) conservation and maintenance of mangrove seedlings, saplings and trees and (2) mangrove species plantation. This design has the purpose to increase mangrove density, biodiversity, ecological function and ecosystem resilience (Macintosh et al., 2002) as a conservation effort of mangrove ecosystem to increase allocation of area to rehabilitate integrated with environmental measures, ecosystem planning and management and complementing the approach of formally protected reserves (Simonsson, Ostlund, \& Gustafsson, 2016)

The first stage, to take the best result of mangrove planting, was the selection of mangrove species based on the best ability of mangrove species to reduce seawater intrusion. Mangrove species have different 
The relation of mangrove grenbelt (Y) and sea water intrusion $(\mathrm{X})$

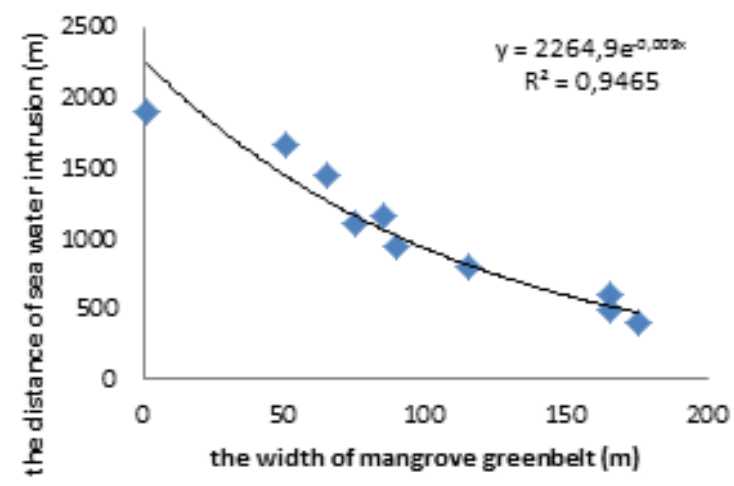

The relation sea water intrusion $(\mathrm{Y})$ and mangrove greenbelt $(\mathrm{X})$

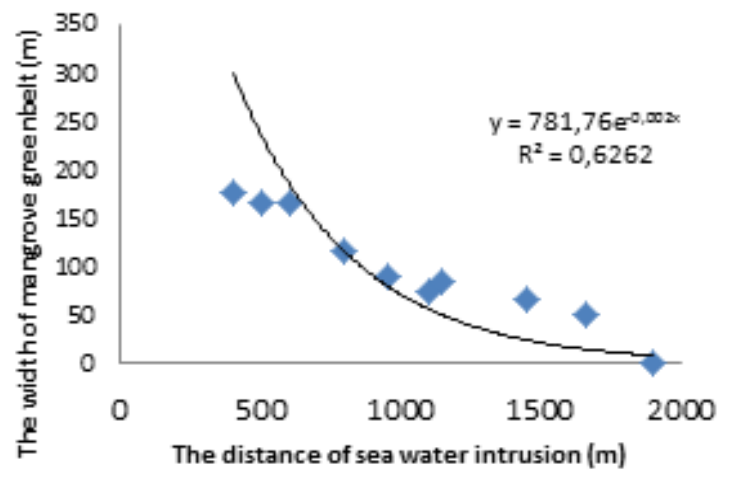

Figure 8. The estimation model for the width of mangrove greenbelt and the distance of seawater intrusion

ability to secrete, accumulate and refuse water salinity. Based on the capacity of water salinity reduction Avicennia marina, Avicennia alba and Sonneratia spp., Rhizophora apiculata, Rhizophora mucronata, Bruguiera spp. are the best suited species for this purpose (Nurmayasri, 1999; Hutchings \& Saenger, 1987; Hilmi, 1998). Basically mangrove plantation will construct a mangrove zone aiming to reduce seawater intrusion and to improve habitat changes, water salinity, soil texture and soil fertility (SandovalCastro et al., 2012)

Therefore, the priority selection of mangrove species in mangrove zone should use the capacity of salt secretion, accumulation and exclusion gland (Macintosh et al., 2002), mangrove density, growth rate, mangrove root, and another environment factors. The dominant species were (1) grade 1 was Avicennia marina, Avicennia alba, Rhizophora stylosa, Sonneratia alba and Sonneratia caseolaris, (2) grade 2 was Rhizophora apiculata, Ceriops spp., Rhizophora mucronata, (3) grade 3 was Bruguiera gymnorrbiza, Bruguiera praviflora, Aegiceras spp., and (4) grade 4 was Xylocarpus spp., and Nypa frutican.

\section{CONCLUSION}

In Jakarta, the existence of mangrove and freshwater demand are the triggering factors for increasing seawater intrusion. The rate of seawater intrusion in Jakarta will reach $0.20 \mathrm{~km}$ year $^{-1}$ (with mangrove) is lower than the rate of seawater intrusion approximately $0.3-0.4$ $\mathrm{km}$ year $^{-1}$ (without mangrove). The mangrove degradation reached 1000.05 ha (over 36 years) from 1165.33 ha (1980) to 165.28 ha (2016). The design of mangrove plantation is used to reduce seawater intrusion.

The width of mangrove greenbelt to reduce seawater intrusion is the width of mangrove greenbelt $(\mathrm{m})=781.76^{*} \exp \left(-0.002^{*}\right.$ seawater intrusion (m)). Based on this equation Jakarta needs a distance of mangrove greenbelt of more than $115 \mathrm{~m}$ with species priority of Avicennia marina, Avicennia alba, Rhizophora apiculata, Rhizophora stylosa, Sonneratia alba and Sonneratia caseolaris.

The activity of coastal rehabilitation to reduce seawater intrusion in Jakarta's coastal area is only using the ability of mangrove vegetations and the width of mangrove greenbelt as the main factors. Therefore, the next research should use the mangrove zone as the important factor to reduce high sea waves, seawater flooding and abrasion.

\section{ACKNOWLEDGEMENTS}

The authors especially thank to the grantsin-aid from the National Ministry of Education of Indonesia (DIKTI) with grant "Hibah 
Kompetensi" and Unggulan Research of Unosed as the financial support to do this research. Special thanks also to the Head of LPPM Jenderal Soedirman University and the Dean of Fisheries and Marine Faculty of the Jenderal Soedirman University. We would also like to thank anonymous reviewers for their helping and constructive comments which greatly helped us improve our manuscript.

\section{REFERENCES}

Acosta, A.B., \& Donado, L.D. (2015). Laboratory scale simulation of hydraulic barriers to seawater intrusion in confined coastal aquifers considering the effects of stratification. $7^{\text {th }}$ Groundwater Symposium of the International Association for HydroEnvironment Engineering and Research (IAHR). Procedia Environmental Sciences, 25, $36-43$.

Al-Nasrawi, A.K.M., Jones, B.G., Hamilton, S.M., 2016. GIS-based modeling of the vulnerability of coastal wetland ecosystems to environmental changes: Comerong Island, southeastern Australia. Journal of Coastal Research, SI (75), 33-37.

Alongi, D.M., Wattayakorn, G., \& Boyle S. (2004). Influence of roots and climate on mineral and trace element storage and flux in tropical mangrove soils. Biogeochemistry, 69,105-123.

Andrari, G., Nandang., Masmui., \& Priyono. (1996). Algorithmic estimation to minimize seawater intrusion in beach aquifer. BPP Teknologi magazine, LXXII. Jakarta.

APHA (American Public Health Association). (2005). Standard methods for the examination of water and wastewater. New York.

Badarudeen, A., Damodaran, K.T., Sajan, K., \& Padmala, D.L. (1996). Texture and geochemistry of the sediments of a tropical mangrove ecosystem, southwest coast of India. Environment geology, 27, 164-169.

Bengen, D.G. (2002). Ecosystem and nature resources of coastal and marine and management principles. Synopsis. PKSPL. Bogor Agriculture Institute, Bogor.

Bengen, D.G., \& Dutton, I.M. (2004). Interaction: mangroves, fisheries and forestry management in Indonesia. In T.G. Northcote and Hartman (Eds), Worldwide watershed interaction and management. Blackwell science. Oxford. UK.

Bosire, J.O., Dahdouh-Guebas, F., Kairo, J.G., Kazungu, J., Dehairs, F., \& Koedam, N. (2005). Litter degradation and $\mathrm{C} / \mathrm{N}$ dynamics in reforested mangrove plantations at Gazi Bay, Kenya. Biological Conservation, 126, $287-$ 295.

Cai, F., Su, X., Liu, J., Li, B., \& Lei, G. (2009). Coastal erosion in China under the condition of global climate change and measures for its prevention. Progress in Natural Science, 19, 415-426.

Carruthers, T.J.B., Beckert, K., Schupp, C.A., Saxby, T., Kumer, J.P., Thomas, J., Sturgis, B., Dennison, W.C., Williams, M., Fisher, T., \& Zimmerman, C.S. (2013). Improving management of a mid-Atlantic Coastal Barrier Island through assessment of habitat condition. Estuarine, Coastal and Shelf Science, 116, 74-86.

Chebo, A.K. (2009). Monitoring wetlands deterioration in the Cameroon coastal lowlands: implications for management. Procedia Earth and Planetary Science, 1, 10101015.

Cochard, R., Ranamukhaarachchi, S.L., Shivakoti. G.P., Shipin, O.V., Edwards, P.J., \& Seelan, K.T. (2008). The 2004 tsunami in Aceh and Southern Thailand: A review on coastal ecosystems, wave hazards and vulnerability. Perspectives in Plant Ecology, Evolution and Systematics, 10, 3-40

Cochran, W.G. (1997). Sampling techniques $\beta^{\text {rd }}$ edition). John Wiley \& Sons.

Ellison, A.M. (2002). Macroecology of mangroves: large-scale patterns and processes in tropical coastal forests. Trees, (2002) 16, 181-194 . doi:10.1007/s00468-001-0133-7.

Ellison, A.M., \& Farmsworth, E.J. (1997). Simulated sea level changes alters anatomy, Physiology, growth, and reproduction of red mangrove (Rhizophora manglr L). Occologia, 112, 435 446.

Ferreira, T.O., Vidal-Torrado, P., Otero, X.L \& Macias, F (2010). Are mangrove forest substrates sediments or soils? A case study 
in southeastern Brazil. Catena 70, 79-91.

Finkl, C.W., (2004). Coastal classification: Systematic approaches to consider in the development of a comprehensive scheme. Journal of Coastal Research, 20 (1), 166 - 213.

Hamilton, L.S., \& Snedaker, S.C. (1984). Handbook for mangrove area management. IUCN Commission on Ecology, Gland.

Hilmi, E. (1998). Estimation of mangrove greenbelt based on system analysis approach (Case study in Muara Angke Jakarta). (Thesis). The Postgraduate Program, IPB. Bogor.

Hilmi, E. (2014). Abrasion reduction based on raising of mangrove ecosystem role as greenbelt. Annual Scientific Meeting of Disaster Research. Surabaya $3-5^{\text {th }}$ June 2014

Hilmi, E., Syakti, A.D., \& Siregar, A.S. (2014). Conservation strategy for coastal and mangrove ecosystem to reduce tsunami disaster, pollution and ability to sequestrate carbon. Final Report of Competence Grant. Universitas of Jenderal Soedirman. Purwokerto.

Howard, K.W.F. (1987). Beneficial aspects of seawater intrusion. Ground Water, 25(4),398-406.

Huang, L., Tan, Y., Song, X., Huang, X., Wang, H., Zhang, S., Dong. J., \& Chen, R. (2003). The status of the ecological environment and a proposed protection strategy in Sanya Bay, Hainan Island, China. Marine Pollution Bulletin, 47, 180-186.

Hussain, M.S., Javadi, A.A., \& Sherif, M.M. (2015). Three dimensional simulation of seawater intrusion in a regional coastal aquifer in UAE. $13^{\text {th }}$ Computer Control for Water Industry Conference, CCWI 2015. Procedia Engineering, 119, 1153 - 1160

Hutchings, P., \&. Saenger, P. (1987). Ecology of mangrove. New York: University of Queensland Press.

Kadlec, R.H. (2008). The effects of wetland vegetation and morphology on nitrogen processing. Ecological Engineering, 33, 126-141.

Kairo, J.G., Dahdouh-Guebas, F., Bosire, J., \& Koedam, N. (2001). Restoration and management of mangrove systems - a lesson for and from the East African region. South African Journal of Botany, 67, 383-389.

Kairo, J.G., Lang'at, J.K.S., Dahdouh-Guebas, F., Bosire, J., \& Karachi, M. (2008). Structural development and productivity of replanted mangrove plantations in Kenya. Forest Ecology and Management, 255, 2670-2677.

Kathiresan, K., \& Bingham, B.L. (2001). Biology of mangroves and mangrove ecosystems. Adv Mar Biology, 40, 238-251.

Kathiresan, K., \& Rajendran, N. (2005). Coastal mangrove forest mitigated tsunami. Estuarine, Coastal and Shelf Science, 65, 601-606.

Krauss, K.W., Lovelock, C.E., McKee, K.L., Hoffman, L., Ewe. S.M.L., \& Sousa, W.P. (2008). Environmental drivers in mangrove establishment and early development: A review. Aquatic Botany, 89, 105-127.

Kusmana, C. (1997). Vegetation survey method. Bogor: IPB Press.

Kusmana, C. (2005). Mangrove ecology. Ecology Laboratory in Forest Faculty IPB, Bogor. P: 150.

Lopes, G.P., Bouillon, S., Mangion, P., Macia, A., \& Paula J., (2009). Population structure, density and food sources of Terebralia palustris (Potamididae: Gastropoda) in a low intertidal Avicennia marina mangrove stand (Inhaca Island, Mozambique). Estuarine, Coastal and Shelf Science, 84, 318-325.

Lunstrum, A., \& Chen, L. (2014). Soil carbon stocks and accumulation in young mangrove forests. Soil Biology \& Biochemistry, 75, 223232.

Machado, W., Moscatelli, M., \& Rezende,L.G. (2002). Mercury, zinc, and copper accumulation in mangrove sediments surrounding a large landfill in southeast Brazil. Environment Pollution, 120, 455-461.

Macintosh, D.J., Ashton, E.C., \& Havanon, S. (2002). Mangrove rehabilitation and intertidal biodiversity: A study in the Ranong Mangrove Ecosystem, Thailand. Estuarine, Coastal and Shelf Science, 55, 331-345.

Marchand, C., Allenbach, M., \& Lallier-Vergès, E. (2011). Relationships between heavy metals distribution and organic matter cycling in mangrove sediments (Conception Bay, New Caledonia). Geoderma, 160, 444 - 456.

Massel, S.R., Furukawa, K., \& Brinkman, R.M. (1999). Surface wave propagation in mangrove forest. Fluid Dynamic Research Elsevier Science, 24, 219 - 249.

Mazda, Y., Kanazawa, N., \& Wolanski, E. (1995). 
Tidal asymetry in mangrove creeks. Hydrobiologia, 295, 51 - 58.

Morgan, L.K., \& Wernera, A.D. (2015). A national inventory of seawater intrusion vulnerability for Australia. Journal of Hydrology: Regional Studies, 4, 686-698.

Muhdin., Suhendang, E., Wahjono, D., Purnomo, H., Istomo., Simanungsong, B.C.H. (2011). The estimation model of Stand Structure Dynamics for Logged-over Natural Forests. Journal of Tropical Forest Management, 17(1), $1-9$.

Nagelkerken, I., Blaber, S.J.M., Bouillon, S., Green, P., Haywood, M., Kirton, L.G., Meynecke, J.O., Pawlik, J., Penrose, H.M., Sasekumar, A., \& Somerfield, P.J. (2008) The habitat function of mangroves for terrestrial and marine fauna: A review. Aquatic Botany, 89, 155-185.

Narayan, K.A., Schleeberger, C., \& Bristow, K.L. (2007). Modelling seawater intrusion in the Burdekin Delta Irrigation Area, North Queensland, Australia. Agricultural Water Management, 89(3), 217-228.

Narayana, A.C., Tatavarti, R., Shinu, N., \& Subeer, A. (2007). Tsunami of December 26, 2004 on the southwest coast of India: Post-tsunami geomorphic and sediment characteristics. Marine Geology, 242, 155-168.

Nurmayasri, T.W. (1999). The growth ability of mangrove trees of Avicennia marina, Bruguiera gymnorrbiza, and Rhizophora mucronata for salinity level. Bandung: Winayamukti University.

Oo, C.W., Kassima, M.J., \& Pizzi, A. (2009). Characterization and performance of Rhizophora apiculata mangrove polyflavonoid tannins in the adsorption of copper (II) and lead (II). Industrial Crops and Products, 30, 152-161

Paris, R., Wassmer, P., Sartohadi, J., Lavigne, L., Barthomeuf, B., Desgages, E., Grancher, D., Baumert, P., Vautier, F., Brunstein, D., \& Gomez, C. (2009). Tsunamis as geomorphic crises: Lessons from the December $26^{\text {th }}$, 2004 tsunami in Lhok Nga, West Banda Aceh (Sumatra, Indonesia). Geomorphology, 104, 59-72

Park, S., Kim, J., Yum, B., \& Yeh, G. (2012). Three-dimensional numerical simulation of saltwater extraction schemes to mitigate seawater intrusion due to groundwater pumping in a coastal aquifer system. Journal of Hydrologic Engineering, 17(1), 10-22.

Parvaresh, H., Abedi, Z., Farshchi, P., Karami, M., Khorasani, N., \& Karbassi, A. (2011). Bioavailability and concentration of heavy metals in the sediments and leaves of grey mangrove, Avicennia marina (Forsk.) Vierh, in Sirik Azini Creek, Iran. Biological Trace Element Research, 143 (2), 1121-1130. doi:10.1007/ s12011-010-8891-y

Patel, A.S., \& Shah, D.L. (2008). Water management: Conservation, harvesting and artificial recharge. New age international (p) limited, publishers.

Petrakis, R., Wu, Z., McVay, J., Middleton, B., Dye, D \& Vogel, J (2016). Vegetative response to water availability on the San Carlos Apache Reservation. Forest Ecology and Management. 378, 14-23.

Pirzan, A.M., Gunarto, R., Daud., \& Burhanuddin. (2004). The relation of soil organic matter, soil texture with macrobenthos diversity in fishpond and mangrove. Jurnal Penelitian Perikanan Indonesia, 10 (20), 27 - 34.

Prahasta, E. (2008). Remote sensing. Bandung: Informatika.

Pramada, S.K., \& Mohan, S. (2015). Stochastic simulation of seawater intrusion into freshwater aquifers. International Conference on Tropical and Coastal Region Eco-Development 2014 (ICTCRED 2014). Aquatic Procedia, 4, 87-94.

Purnobasuki, H \& Suzuki, M (2004). Root system architecture and gravity perception of a mangrove plant, Sonneratia alba J. Smith. Journal of Plant Biology, 47(3), 236-243.

Purwadhi, S. H. (2001). Satellite imagery interpretation. Jakarta: PT. Grasindo.

Robins,P.E., Skov, M.W., Lewis, M.J., Gimenez, L., Davies, A.G., Malham, S.K., Neill, S.P., McDonald, J.E., Whitton, T.A., Jackson , S.E \& Jago, C.F (2016). Impact of climate change on UK estuaries: A review of past trends and potential projections. Estuarine, Coastal and Shelf Science. 169, 119-135.

Salampessy, M.L., Febryano, I.G., Martin, E., Siahaya, M.E., \& Papilaya, R. (2015). Cultural capital of the communities in the mangrove conservation in the coastal areas 
of Ambon Dalam Bay, Moluccas, Indonesia. (2015) International Conference on Tropical and Coastal Region Eco-Development 2014 (ICTCRED 2014). Procedia Environmental Sciences, 23, $222-229$.

Sandoval-Castro, E., Mu niz-Salazar, R., EnríquezParedes, L.M., Riosmena-Rodríguez, R., Dodd, R.S., Tovilla-Hernández, C., \& Arredondo-García, M.C. (2012). Genetic population structure of red mangrove (Rhizophora mangle L.) along the Northwestern Coast of Mexico. Aquatic Botany, 99, 20- 26.

Sigalingging, M. (1985). Land use and soil reclamation in seawater intrusion area in North Indramayu. (Thesis). The Postgraduate Program IPB, Bogor.

Simonsson, P., Ostlund, L \&Gustafsson, L (2016). Conservation values of certified-driven voluntary forest set-asides. Forest Ecology and Management, 375, 249-258.

Snedaker, S.C., \& Snedaker, J.G. (1984). The mangrove ecosystem : research methods. UNESCO

Soerianegara, I. (1987). The widht of mangrove green belt as coastal zone protection forest. Media Konservasi, 1(4), 21-30.

Soil Research Department of Agriculture Ministry. (2005). The analysis of soil chemical, plant, water and fertilizer. Jakarta.
Steel, R.G.D \& Torrie, J.H. (1980). Principles and procedures of statistics (A biometrical approach). ( $2^{\text {nd }}$ edition). New York: McGraw - Hill.

Suhartono, E., Purwanto, P., \& Suripin, S. (2015). Seawater intrusion modeling on groundwater confined aquifer in Semarang. International Conference on Tropical and Coastal Region Eco-Development 2014 (ICTCRED 2014). Procedia Environmental Sciences, 23, 110 - 115.

Todd, D.K. (1980). Groundwater bydrology (2 ${ }^{\text {nd }}$ editons). New York-Chichester-BrisbaneToronto-Singapore: John Wiley \& Sons.

Wang, Y., Qiu, Q., Xin, G., Yang, Z., Zheng, J., Ye Z., \& Li, S. (2013). Heavy metal contamination in a vulnerable mangrove swamp in South China. Environment Monitoring Assesment. 185 (7), 5775-5787. doi:10.1007/s10661-0122983-4.

Xiao, Y., Jie, Z., Wang, M., Lin, G.I., \& Wang, W. (2009). Leaf and stem anatomical responses to periodical waterlogging in simulated tidalfloods in mangrove Avicennia marina seedlings. Aquatic Botany, 91, 231-237.

Xiao, Y., Wang, W., \& Chen, L. (2010). Stem anatomical variations in seedlings of the mangrove Bruguiera gymnorrbiza grown under periodical waterlogging. Flora, 205, 499-505. 